\title{
Use of cutting-edge technology to learn myocardial cutting edge in septal myectomy
}

\author{
Yuting P. Chiang, MD, ${ }^{\mathrm{a}}$ Jonathan N. Ginns, $\mathrm{MD},{ }^{\mathrm{b}}$ and Hiroo Takayama, MD, $\mathrm{PhD}^{\mathrm{a}}$
}

\footnotetext{
From the a Division of Cardiothoracic Surgery, Department of Surgery, Columbia University Medical Center, New York, NY; and ${ }^{\mathrm{b}}$ Division of Cardiology, Department of Medicine, Weill Cornell Medical Center, New York, NY.

Disclosures: Authors have nothing to disclose with regard to commercial support.

Received for publication Oct 18, 2017; accepted for publication Oct 27, 2017; available ahead of print Nov 29, 2017.

Address for reprints: Hiroo Takayama, MD, PhD, Division of Cardiothoracic and Vascular Surgery, Department of Surgery, Milstein Hospital Bldg, 177 Fort Washington Ave, Ste 7-435, New York, NY 10032 (E-mail: ht2225@ cumc.columbia.edu).

J Thorac Cardiovasc Surg 2018;156:1149-50

$0022-5223 / \$ 36.00$

Copyright (C) 2017 by The American Association for Thoracic Surgery

https://doi.org/10.1016/j.jtcvs.2017.10.108
}

Septal myectomy (SM) is among the most challenging procedures to learn and teach. Although schematic illustrations usually present a conceptually simple image of a knife resecting muscle protruding obviously into the left ventricular outflow tract, ${ }^{1}$ in practice, ascertaining the appropriate amount of septal tissue to resect intraoperatively can be difficult and requires hands-on experience. The low volume of SM performed at most centers and the difficult that trainees usually have visualizing the surgical field exacerbate this teaching challenge.

SM is the guideline-recommended first-line septal reduction therapy for patients with symptomatic obstructive hypertrophic cardiomyopathy. ${ }^{2,3}$ The main advantage that SM holds over alcohol septal ablation is the durability of long-term symptom relief and decreased need for subsequent reintervention. ${ }^{4-6}$ However, the difficulty of teaching SM has likely been an important factor in the current shortage of cardiac surgeons familiar with this procedure.

Hermsen and colleagues ${ }^{8}$ propose an exciting solution to this problem: Expert-guided simulation of SM using 3 -dimensional printed models. In their study, ${ }^{8}$ cardiac surgery trainees performed SM on a series of 5 hydrogel 3 -dimensional models based on 5 actual patients with hypertrophic cardiomyopathy. As can be seen in the provided figures and video clip, the exercise offers an impressively realistic simulation of SM. The models replicate the experience of operating via an aortotomy and are printed with high enough fidelity that anatomic landmarks such as the right coronary ostium, right aortic annulus, and fibrous trigones can be identified.

The authors ${ }^{8}$ demonstrate that serial simulation improves the technical outcome. Whereas trainees initially tended to be overly cautious (resecting on average $3 \mathrm{~cm}^{3}$ of tissue compared with the $15 \mathrm{~cm}^{3}$ of tissue resected by the attending physician), during subsequent simulations they resected increasingly larger volumes (on average adding $3.6 \mathrm{~cm}^{3}$ per simulation). Given

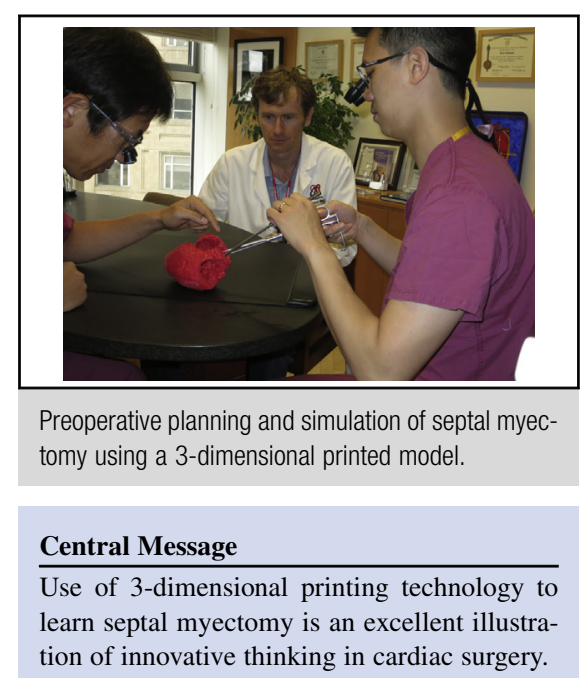

See Article page 1139.

that the success of SM and its advantage over alcohol septal ablation is primarily based on the ability to resect an adequate volume and extent of tissue, these results are impressive.

This report also highlights the subjective nature of SM. ${ }^{8}$ Each simulation was videotaped and assessed by multiple faculty members who assigned scores. Interrater agreement among these faculty assessments was poor. Given the same simulation, 1 of the 3 faculty raters gave significantly higher ratings compared with the others, suggesting that what appears to be an adequate resection to 1 surgeon may appear inadequate to the next. Inconsistency regarding the assessment of the resection presents a challenge to both teacher and student and is an area that calls for better standardization of SM.

Simulation might be further improved by incorporating pathologies of the mitral valve, which have been increasingly appreciated as a major player in the development of left ventricular outflow tract obstruction. ${ }^{9}$ A thorough curriculum would include teaching adjunctive procedures such as shaving of hypertrophied papillary muscles or plication of an abnormally elongated anterior mitral leaflet.

Nonetheless, innovations like those described by Hermsen and colleagues ${ }^{8}$ that incorporate cutting-edge technology to teach trainees how to determine the appropriate cut edge of the hypertrophied myocardium in SM are needed and should be commended. 


\section{References}

1. Schaff HV, Said SM. Transaortic extended septal myectomy for hypertrophic cardiomyopathy. Operat Techniq Thorac Cardiovasc Surg. 2012;17:238-50.

2. Gersh BJ, Maron BJ, Bonow RO, Dearani JA, Fifer MA, Link MS, et al. 2011 ACCF/AHA guideline for the diagnosis and treatment of hypertrophic cardiomyopathy: a report of the American College of Cardiology Foundation/American Heart Association Task Force on Practice Guidelines. J Am Coll Cardiol. 2011; 58:2703-38.

3. Elliott PM, Anastasakis A, Borger MA, Borggrefe M, Cecchi F, Charron P, et al 2014 ESC Guidelines on diagnosis and management of hypertrophic cardiomyopathy. Eur Heart J. 2014;35:2733-79.

4. Maron BJ, Nishimura RA. Surgical septal myectomy versus alcohol septal ablation: assessing the status of the controversy in 2014. Circulation. 2014;130:1617-24.

5. Vriesendorp PA, Liebregts M, Steggerda RC, Schinkel AF, Willems R, Ten Cate RJ, et al. Long-term outcomes after medical and invasive treatment in patients with hypertrophic cardiomyopathy. JACC Heart Fail. 2014;2: 630-6.

6. Liebregts M, Vriesendorp PA, Mahmoodi BK, Schinkel AF, Michels M, ten Berg JM. A systematic review and meta-analysis of long-term outcomes after septal reduction therapy in patients with hypertrophic cardiomyopathy. JACC Heart Fail. 2015;3:896-905.

7. Maron BJ, Rastegar H, Udelson JE, Dearani JA, Maron MS. Contemporary surgical management of hypertrophic cardiomyopathy, the need for more myectomy surgeons and disease-specific centers, and the Tufts initiative. Am J Cardiol. 2013;112:1512-5.

8. Hermsen JL, Yang R, Burke TM, Dardas T, Jacobs LM, Verrier E D. Development of a $3 \mathrm{D}$ printing based cardiac surgical curriculim to teach septal myectomy. J Thorac Cardiovasc Surg. 2018;156:1139-48.e3.

9. Sherrid MV, Balaram S, Kim B, Axel L, Swistel DG. The mitral valve in obstructive hypertrophic cardiomyopathy. J Am Coll Cardiol. 2016;67:1846-58. 